\title{
VAIKO DALYVAVIMAS: SVEIKATOS APSAUGA IR TEISE PRIIMTI SPRENDIMUS
}

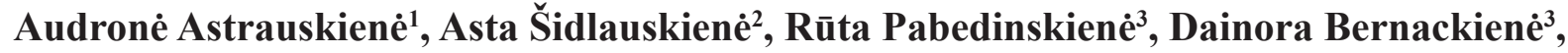 \\ Justina Alsytè-Gogeliené ${ }^{4}$ \\ ${ }^{1}$ Vilniaus universiteto Medicinos fakulteto Sveikatos mokslu institutas, \\ ${ }^{2}$ Viešoji ìstaiga Socialinès partnerystès centras, ${ }^{3}$ Viešoji ìstaiga Vaiko teisiu institutas, \\ ${ }^{4}$ Viešoji ìstaiga Social smart
}

Raktažodžiai: vaiko teisès, vaiko dalyvavimas, vaiko geriausi interesai.

\section{Santrauka}

Vertinant vaiko dalyvavimo teisę, kaip principinį vaiko teisių apsaugos elementą, svarbu akcentuoti, kad vaiko dalyvavimas sudaro sąlygas ir prielaidas užtikrinti vaiko, kaip savo teisių turetojo, dalyvavimą tiek šeimos, tiek ir visuomeniniame gyvenime. Užtikrinant vaiko dalyvavimą ir išklausant vaiko nuomonę, sveikatos apsaugos sistemoje atsiranda sąlygos vaikui turèti įtakos sveikatinimo procesui ir ịtraukti vaiką i i ši procesą kaip lygiateisį subjektą, kuri atstovauja tevvai ar kiti vaiko atstovai pagal įstatymą. Vaiko dalyvavimo principas atskleidžiamas per vaiko teisių igyvendinimą ir geriausių interesų užtikrinimą. Straipsnyje apžvelgtos vaiko teisių i dalyvavimą priimant sprendimus sveikatos priežiūros srityje tendencijos, aktualijos bei pokyčiai Lietuvoje Jungtinių Tautų vaiko teisių konvencijos (JTVTK), Europos Tarybos vaiko teisių strategijos 2016-2021 m., Pasaulio sveikatos organizacijos bei sveikatos priežiūros ir švietimo sistemas reglamentuojančių teisès aktų kontekste. Tyrimo tikslas - atskleisti ir išanalizuoti vaiko dalyvavimo sveikatos apsaugos srityje, kaip principinio vaiko teisių elemento, sudarančio sąlygas ir galimybes jam dalyvauti šeimos ir visuomeniniame gyvenime ar kitoje veikloje bei priimti sprendimus, aktualijas ir tendencijas. Tyrimo medžiaga ir metodai. Atlikta dokumentų, dokumentų komentarų ir straipsnių vaiko teisių apsaugos klausimais apžvalga ir vertinimas. Apžvalgai naudoti tarptautiniai ir nacionaliniai dokumentai, reglamentuojantys vaiko teisių apsaugą, apibrěžiantys vaiko dalyvavimo principa, straipsniai, kuriuose analizuojamas vaiko dalyvavimas, kaip vienas iš pagrindinių vaiko teisių elementų.

\section{Ivadas}

XX amžiaus pabaigoje vaiko sveikata ir jos užtikrinimas pradètas apibrèžti, akcentuojant paties vaiko dalyvavimą ir aktyvų santykį su aplinka. Istoriškai vaikas visada buvo laikomas šeimos dalimi, todèl, kai vaiko interesų sąvoka buvo įtraukta į žmogaus teisių sampratą, vaiko teisès nebuvo pripažintos kaip visavertès žmogaus teisès ir neapèmè jų turinio.

Šiuo straipsniu siekiama apžvelgti vaiko teisès ị dalyvavimą sveikatos priežiūros srityje tendencijas, aktualijas bei pokyčius Lietuvoje Jungtinių Tautų vaiko teisių konvencijos (JTVTK), Europos Tarybos vaiko teisių strategijos 20162021 m., sveikatos priežiūros ir švietimo sistemas reglamentuojančių teisès aktų kontekste.

Tyrimo tikslas - atskleisti ir išanalizuoti vaiko dalyvavimo sveikatos apsaugos srityje, kaip principinio vaiko teisių elemento, sudarančio sąlygas ir galimybes jam dalyvauti šeimos ir visuomeniniame gyvenime ar kitoje veikloje bei priimti sprendimus, aktualijas ir tendencijas.

\section{Tyrimo medžiaga ir metodai}

Atlikta dokumentų, dokumentų komentarų ir straipsnių vaiko teisių apsaugos klausimais apžvalga ir vertinimas. Apžvalgai naudoti tarptautiniai ir nacionaliniai dokumentai, reglamentuojantys vaiko teisių apsaugą, apibrèžiantys vaiko dalyvavimo principą, straipsniai, kuriuose analizuojamas vaiko dalyvavimas, kaip vienas iš pagrindinių vaiko teisių elementų.

\section{Tyrimo rezultatai}

Pagrindiniai JTVTK 3 straipsnio 1 dalies principai buvo aptarti ir nustatyti jau iki 1980 m., t. y. gerokai anksčiau, negu buvo baigtas vaiko teisių igyvendinimo žmogaus teisių kontekste svarstymas ir priimtas sprendimas. Svarbiu aspektu tapo vaiko geriausi interesai, nes jie neatskiriamai susiję su 
vaiko teisiu igyvendinimo klausimais. Vertinant vaiko teisių iggyvendinimo problematiką, vaiko ,geriausių interesų“ sąvoka nebuvo išsamiai nagrinejjama ir akcentuojama, nes nuostatos, užtikrinančios pagrindines žmogaus teises, sudare prielaidas užtikrinti vaiko teises, tarp jų ir vaiko geriausius interesus, neįvertinant paties vaiko galimybių dalyvauti, todèl tokia vaiko „geriausių interesų“ sąvoka tapo neaktuali, o neretai ir galinti turèti neigiamos įtakos, igyvendinant JTVTK nuostatas pagrindinių žmogaus teisių kontekste.

Daugelis nuorodų i geriausius vaiko interesus pagal JTVTK nesudaro prielaidų vienodam vaiko, kaip žmogaus teisių subjekto, teisių traktavimui, todèl gali būti keliama diskusija, ar tos teisès turi būti taikomos ir ginamos išskirtinai tik kaip vaiko teisès.

JTVTK 3 straipsnis apibrèžia vaiko interesų sąvoką, kuri yra unikali žmogaus teisių sutarties nuostata, nustatanti principą, kuriuo vadovaujamasi priimant sprendimus ir veiksmus, turinčius įtakos tiek individualiam, tiek visuomeniniam vaikų gyvenimui. Šis principas nustatytas, pripažįstant, kad vaikai, kaip ir suaugusieji, yra žmogaus teisių subjektai, tačiau, priešingai nei suaugusieji, vaikai neturi visiškos autonomijos ir teisès savarankiškai priimti sprendimus savo gyvenimo atžvilgiu. Atsižvelgiant ị tai, jog valstybès sutarè, kad vaikas yra žmogus, neturintis aštuoniolikos metų, JTVTK 1 straipsnio nuostatos, atitinkamai ir jo, kaip žmogaus, visapusių teisių ir laisvių iggyvendinimas ribojamas tėvų (globejų̧) pareigų ir valdžios kontekste [1].

Atsižvelgiant ị vaiko teisių ribojimus amžiaus atžvilgiu, tarptautiniame lygmenyje buvo sutarta dèl ,geriausių interesų“ principo taikymo, siekiant nustatyti ribas ir sutelkti dèmesị i suaugusiuosius asmenis, kurie turi teisę ir pareigą priimti sprendimus vaiku, kaip individų, vardu, taip pat priimti ir igyvendinti valstybès ir tarptautinius politinius sprendimus vaikų atžvilgiu. JTVTK vaiko „geriausių interesų“ principas pirmiausia taikomas tèvams ir visiems kitiems asmenims, kurie turi teisę ir (ar) ịgaliojimus vaikų gyvenime, ar kurių veiksmai daro poveikị vaikams, taip užtikrinant ju teises ir geriausius interesus teismuose, socialinejje, sveikatos priežiūros, švietimo, teisès ir bendrojoje politikos formavimo srityje [1].

Galima rizika, kad „geriausių interesų“ principas gali būti klaidingai suprastas ir (ar) taikomas. Klaidingas geriausių vaiko interesų principo supratimas ir (ar) taikymas gali pakenkti vaiko teisių įgyvendinimui ar net kelti grèsmę vaikui. Šis vaiko ,geriausių interesų“ principas gali būti dažnai naudojamas, siekiant pateisinti bet kokị veiksmą, kuri pasirenka suaugę asmenys, turintys valdžią prieš vaikus. Istorijoje galima rasti nemažai suaugusiujų politikos ir veiksmų pavyzdžių, kurie tam tikru metu ir tam tikromis aplinkybėmis buvo propaguojami kaip naudingiausi vaiku interesams, tačiau vèliau įvertinti kaip diskriminacinio pobūdžio, neužtikrinę vaiko sveikos gyvensenos ir raidos galimybių. Suaugusieji dèl savo subjektyvaus gebėjimo ịvertinti vaiko poreikius ir interesus ne visada vaiko atžvilgiu priima sprendimus, atitinkančius vaiko geriausius interesus. Kita vertus, suaugusių priimami sprendimai konkrečiu momentu ar laikotarpiu atitinka teisines ir moralines laikmečio normas [1].

Siekdamas vaiko teisių užtikrinimo esant ịvairių ,geriausių interesų“ principo taikymo interpretacijų, Jungtinių Tautų Vaiko teisių komitetas apibrěže šio principo sampratą:

a) materialinè teisè, reiškianti vaiko teisę, nurodančią, kad vaiko interesai turi būti ịvertinti ir ị juos būtų atsižvelgta, kai svarstomi skirtingi interesai ir siekiama priimti sprendimą, bei garantija, kad ši teisè bus igyvendinta kiekvieną kartą, kai yra priimamas su vaiku ar vaikų grupemis susijęs sprendimas;

b) pagrindinis aiškinamasis teisès principas, reiškiantis, kad, jeigu teisinę nuostatą galima aiškinti keliais būdais, būtina pasirinkti tą aiškinimą, kuris geriausiai atitinka vaiko interesus;

c) darbo tvarkos taisyklè, reiškianti, kad priimant sprendimą, kuris darys įtaką konkrečiam vaikui, vaikų grupei ar visiems vaikams, sprendimo prièmimo procesas turètu apimti galimo tokio sprendimo poveikio (teigiamo ar neigiamo) susijusiam vaikui ar vaikams vertinimą. Siekiant ịvertinti ir nustatyti vaiko interesus, būtinos procedūrinès garantijos. Be to, sprendimo pagrindimas turètų parodyti, kad ị tokią teisę buvo aiškiai atsižvelgta. Tokiu atveju, valstybès dalyvès privalo paaiškinti, kaip tokia teise buvo gerbiama sprendime, $t$. y. kas atitiko vaiko interesus, kokiais kriterijais buvo remtasi, kaip vaiko interesai buvo ịvertinti [2].

Atsižvelgiant ị šias nuostatas, visi su vaikais susiję veiksmai turi būti nukreipti ị vaikų teisių igyvendinimą ir negali būti pateisinami kaip vaiko geriausių interesų užtikrinimas, jei jais siekiama pažeisti ir (ar) riboti vaiko teises.

Svarbu laikytis holistinio požiūrio ị vaikų teisių igyvendinimą. Priemonès, užtikrinančios vaiko teisę i geriausią galimą sveikatą, negali būti veiksmingos vien tik teikiant asmens ir visuomenès sveikatos priežiūros paslaugas. Būtina ịgyvendinti vaiko teisę $i \mathfrak{s}$ šeimą, i švietimą, teisę žaisti, ị tinkamą gyvenimo lygị, socialines ekonomines sąlygas, ị vaiko pažiūras, įvertinant jo amžių, brandą, gebejjimus, suteikiant daugiau teisių vaikui priimti sprendimus savo paties interesų atžvilgiu [1].

JTVTK 5 straipsnis, nustatantis vaiko gebejjimų raidos koncepciją, numato pereinamaji ryši tarp pradinès vaiko priklausomybès (neveiksnumo) ir visiškos suaugusiojo autonomijos (veiksnumo). Straipsnis nurodo, kad bet koks tèvų ar globėjų valdžios turinys ar taisyklès gali būti tinkamos, 
jeigu jos suderintos su vaiko gebejjimais ir skirtos vaikui igyvendinti savo žmogaus teises. Suaugusiujų veiksmai ir sprendimai turi atitikti vaiko teises ir laipsniškai, vaikui augant ir bręstant, sprendimas perduodamas iš suaugusiujų vaikui, nes vaikas igyja gebejimą prisiimti atsakomybę už priimamą sprendimą [3]. Vaiko gebejjimas prisiimti atsakomybę už priimamą sprendimą formuojasi jo dalyvavimo priimant sprendimą, galimybès išreikšti savo nuomonę ir būti išklausytam, pagrindu.

JTVTK 5 straipsnį papildo JTVTK 12 straipsnis, kuriame akcentuojama, kad vaikai turi teisę pareikšti savo nuomonę visais su vaikais susijusiais klausimais, o ị vaikus turi būti žiūrima su pagarba ir supratimu. Vaiko teisių komitetas nustate, kad kuo daugiau vaikas žino, patiria ir supranta, tuo daugiau tèvai, teisèti globejai ir kiti teisiškai už vaiką atsakingi asmenys privalo keisti auklèjimo, priežiūros ir ugdymo metodus ir modelius, laipsniškai pereinant prie bendravimo su vaiku lygiomis teisèmis. Kūdikiai ir maži vaikai turi tokias pačias teises kaip ir visi vaikai, kad būtų atsižvelgta ị jų interesus, net jeigu jie negali išreikšti savo pažiūrų ar sau atstovauti kaip vyresni vaikai [2].

JTVTK aiškiai pripažista, kad vaikas yra savo teisių subjektas ir aktyvus dalyvis, igyvendinant šias teises ne tik vadovaujantis 12 straipsnio nuostatomis, bet ir teises i saviraiškos, minties, sąžinès ir religijos laisvę, susivienijimą, privatumą ir informaciją. Pastaraisiais metais daugèja praktinių atvejų, kurie parodo, kokią naudą vaikui teikia jo nuomonès išklausymo, vertinimo ir pagarbos patirtis. Tai formuoja vaiko didesnị pasitikèjimą savimi, igūdžių igijimą, geresnę emocinę būklę, psichikos ir fizinę sveikatą bei gerovę [4].

Esminiai elementai, užtikrinantys vaiko teisių igyvendinimą, yra vaiko nuomonè ir požiūris, vaiko tapatybè, šeimos aplinkos išsaugojimo ir šeiminių santykių palaikymas, vaiko priežiūra, apsauga ir saugumas, pažeidžiamumo situacijų prevencija, vaiko teisè ị sveikatą, mokslą ir dalyvavimą. Pagrindinis vaiko geriausių interesų vertinimas yra kompleksinio pobūdžio, kartu vertinant visus aktualius vaiko interesų elementus. Kiekvieno minèto elemento turinys gali skirtis ir būti individualus, priklausomas nuo vaiko ir kiekvieno konkretaus atvejo, nuo sprendimo ir konkrečių aplinkybių, nuo kiekvieno elemento svarbos ir reikšmingumo bendrajame vertinime [5].

Akcentuojant vaiko vystymosi svarbą, visavertiško gyvenimo ir raidos užtikrinimas siejamas su vaiko sveikatos samprata, apimančia tokius aspektus, kaip kiekvieno vaiko savirealizacijos galimybès, jo poreikių tenkinimas, galimybès plètoti savo gebejjimus, kurie padeda sèkmingai vystytis ir veikti biologineje, fizinejje ir socialinèje aplinkoje [6].

Pastaraisiais metais vis labiau atkreipiamas demesys ir pripažịstama, kad vaikų dalyvavimas sveikatos sistemoje yra neatsiejamas, siekiant geriausių vaiko sveikatos priežiūros rezultatų. Vaikams turètų būti teikiama informacija apie jų sveikatos būklę, atsižvelgiama į vaiko nuomonę kai kuriais sveikatos priežiūros klausimais. Vaikai turi būti skatinami rūpintis savo ir aplinkos sveikata [3].

Teismų sprendimai dèl vaiko įkurdinimo šeimoje, ịvaikinimo ar globos organizavimo yra priimtinesni vaiko atžvilgiu, jei atsiranda ir sudaromos galimybès išklausyti vaiko nuomonę jam svarbiu klausimu, atskleisti vaiko pažiūras ir patirti, kuri taip pat yra labai svarbi priimant sprendimus vaiko atžvilgiu. Pavyzdžiui, Europos Sajungoje atlikus vaikų dalyvavimo vertinimą, visose valstybėse narėse nustatyta, kad yra akivaizdus ryšys tarp vaikų, sèkmingai besinaudojančių teise būti išklausytam, sprendžiant jų statuso arba asmeninių aplinkybių gerinimo klausimus, ir vaikų, kuriems nesuteikta galimybė būti išklausytam. İrodyta, kad nebus pasiekta vaiko geriausio vystymosi ir geriausių interesu užtikrinimo, jei nebus atsižvelgiama ị vaiko nuomonę ir perspektyvas [4].

JTVTK aiškiai pripažįsta, kad dèl vaikų, kaip tikslinès socialinès grupès, didesnio pažeidžiamumo ir kintančių gebèjimų, vaikai turi teisę ị papildomą apsaugą. Teisès ị apsaugą nuo smurto, ekonominio ir seksualinio išnaudojimo, ginkluotų konfliktų, minimalaus santuokinio amžiaus arba darbo visą darbo dieną nustatymas, jei būtina, alternatyvios priežiūros taikymas patvirtina suaugusiujų atsakomybę, užtikrinant, kad vaikai nepatirtų žalos ir pavojaus, kuris pakenktų jų interesams.

Vaiko teisių apsaugos, kaip ir kitų teisių srityje, vaikų interesai bus geriausiai tenkinami, ịsipareigojant užtikrinti, kad vaikų balsas bus išgirstas. Vaikas nèra tik pasyvus savo teisių subjektas. Atsiranda daug pagrịstų ịrodymų, kad daugelị metų nebuvo atskleisti seksualiniai nusikaltimai prieš vaikus įstaigose, bendruomenèse ar šeimose dèl nesugebejjimo tinkamai išklausyti vaikų [7]. Vaikai dažnai geriau supranta, su kokiais pavojais jie susiduria, supranta smurto pobūdị ir galimas strategijas, kurių reikia, kad smurtas būtų nutrauktas, tačiau vaikams yra sunku apsaugoti save nuo smurto patiems, nes dèl patirties, žinių ir i̇gūdžių trūkumų, negalejjimo ar nesamų sąlygų išsakyti savo nuomonę ir būti tinkamai apsaugotam, vaikų veiksmai gali prieštarauti paties vaiko geriausiems interesams.

Klaidingo geriausių interesų principo taikymo rizika kyla ir tada, kai vaiko geriausių interesų principas priimamas kaip atskiras principas. Tokios praktikos neturètų būti. Vaiko „geriausių interesų“ principas visada turètų būti vertinamas kaip vaiko teisių apsaugos visumos proceso esminis elementas. Tokių kraštutinumų atsiradimą lemia siekis pateisinti sisteminius ir (ar) individualius sprendimus, ar bendrosios praktikos taikymas, imantis veiksmų ar priimant sprendimus, 
kurie iš esmès gali prieštarauti geriausiems vaiko interesams konkrečiu atveju.

Tarptautinès organizacijos Eurochild atliktų tyrimų rezultatai rodo, jog vaikai tvirtai tiki, kad jie turi tureti balsą ir vaikų nuomone turi būti išklausyta, priimant pagrindinius sprendimus, kurie turi įtakos vaikų gyvenimui. Vaikai nori, kad su jais būtų konsultuojamasi, kad jie būtų išklausyti ir kad ị jų nuomonę būtų atsižvelgiama [8].

Vaiko dalyvavimo ir lūkesčiu patenkinimo mastas praktikoje labai skiriasi. Kai kuriose Europos valstybèse vaikai dažnai neišklausomi, net jei yra tam tikslui priimti teisès aktai. Europos Tarybos konsultacijų Moldovoje ir Slovakijoje rezultatai parodè, kad daugelis vaikų jaučiasi negirdimi $[9,10]$. Suaugusieji ir vaikai dažnai nežino, ką reiškia vaikų dalyvavimas ir kaip ịgyvendinti šią teisę. Tiksliniame tyrime 50 proc. vaikų pranešè, kad suaugę „,visada“ arba „didžiausią laiko dalį“" klausèsi, ką vaikai turèjo pasakyti, 36 proc. vaikų teigè, kad jie buvo išklausyti „kartais“. Tik 5 proc. vaikų teigè, kad suaugusieji niekada jų neišklausè. 96 proc. vaikų teigé, kad tėvai ar globejjai, mokytojai ar bendraamžiai jiems dažnai sakè, kad vaikai turi teisę būti išklausyti ir reikia atsižvelgti ị vaikų nuomonę [11]. Didžiosios Britanijos nacionaliniai tyrimai apie sveikatos priežiūrą, vietos paslaugų kokybę ir pilietinę veiklą dažnai neklausia vaikų ir jaunimo nuomonès apie jų patirtị. Labiausiai su vaikų padètimi susijusiuose sprendimuose dèl asmens sveikatos priežiūros, privatinės teisès procedūrų, vaikų apsaugos tyrimų, imigracijos ir prieglobsčio prašymo proceso bei mokyklos atskirties, vaikų nuomonès dažnai nesiekiama sužinoti [11]. Panašios išvados padarytos ir kitose šalyse. Tyrimai rodo, jog dauguma vaikų manè, kad jų nuomonès buvo išklausytos ir i jas atsižvelgiama, kai jie dalyvauja neformaliose struktūrose, šeimoje ir bendrauja su mokyklų bei sveikatos priežiūros darbuotojais [12]. Vaikai buvo mažiau išklausyti kitose vietose, pavyzdžiui, vietos ir nacionalinèje administracijoje, santykiuose su advokatais ir teisejais, vaiku globos įstaigose, žiniasklaidoje. Vaikų dalyvavimo patirtis skiriasi priklausomai nuo jų gyvenimo sąlygu, vietos ir individualiu veiksnių (pvz., amžius, lytis, etninė kilmè, negalia). Vaikų dalyvavimas ir nuomonès išklausymas yra glaudžiai susijęs su valstybès turima tradicija, kultūra ir valdymo struktūra, tiesiogiai igyvendinančia vaiko teises [13].

Vaikų dalyvavimui kyla ịvairios kliūtys, nes suaugusieji dažnai mano, kad patys žino, kas geriausia vaikams ir prisiima atsakomybę už priimamą sprendimą vaiko atžvilgiu. Suaugusieji tokiu sprendimu esamuoju momentu daro tiesioginę ar netiesioginę įtaką vaiko gyvenimui ir sveikatai, kuri ateityje gali paveikti vaiko socialinę, darbo, karjeros ir šeiminę padètị. Vaikai nurodo jų visaverčio dalyvavimo ir nuomonès išklausymo kliūtis, tai nepakankamas laikas tin- kamam dalyvavimui, kalbos sunkumai ir skirtumai (vaikui sudètinga išreikšti savo nuomonę), kultūriniai ir religiniai veiksniai ar nesaugios gyvenimo sąlygos šeimoje ar bendruomenėje. Pažymėtina, kad procedūros, susijusios su vaiku, gali būti per ilgos arba pernelyg sudètingos, kad vaikai galètų apginti savo teises [14]. Buvo nustatyta, kad teigiama patirtis yra labiau tikètina, kai yra sąžiningumo ir pagarbos kultūra, kai visi supranta, kodèl svarbu, kad vaikai ir jaunimas dalyvautu, kai teikiama papildoma parama, kai vaikai ir jaunimas gali dalyvauti jiems pritaikytuose ir neprivalomuose sprendimuose [15].

Vaikai, gaudami pakankamai informacijos sveikatos, laisvalaikio ar kitokios sociokultūrinès veiklos klausimais, gali tinkamai ịvertinti esamą situaciją ir inicijuoti veiklą, kuri padètų ištirti veiksnius, turinčius įtakos jų sveikatai. R. Hart teigimu, vaikai gali dalyvauti sveikatos stiprinimo veikloje, išsakyti savo nuomonę ir kartu atskleisti gebejjimus, parodyti iniciatyvą [16]. Gali būti ir priešinga reakcija, tokia, kaip vaikų nedalyvavimas ar dalyvavimas tik dèl to, kad liepè suaugusieji. Tokiu atveju suaugusiųjų uždavinys - tinkamai nukreipti vaikus, išaiškinti ir suteikti paramą, nepamirštant taisyklès - daryti viską ne „dèl vaiko“, o „su vaiku“". Institucijos, igyvendindamos teisès aktuose numatytus uždavinius, turi siekti sukurti kuo tinkamesnes sąlygas vaikų visapusiam vystymuisi, užtikrindamos jų teisę ị sveiką ir saugią aplinką, sveikatos apsaugą, socialinị aprūpinimą, vaiko dalyvavimą ir nuomonès išklausymą, sprendžiant su juo susijusius klausimus.

Sveikatos apsaugos srityje vaiko dalyvavimas yra vienas iš esminių elementų, užtikrinant geriausius vaiko interesus. Vaikui pagal jo amžių ir gebẻjimą suprasti turi būti suteikta reikalinga informacija apie sveikatą ir išklausoma jo nuomonè. Sudètingesniu klausimu, pvz., dèl vaiko dalyvavimo biomedicininiame tyrime, asmens sutikimą duoda vaiko atstovai pagal ịstatymą, tačiau, jeigu vaikas, gebantis suprasti jam pateiktą informaciją, pareiškia norą nedalyvauti biomedicininiame tyrime ar jeigu jis tokiame tyrime jau dalyvauja, vaiko dalyvavimas tyrime nepradedamas ar nutraukiamas, išskyrus atvejus, kai tai prieštarauja paties vaiko interesams. Ar vaiko noras nedalyvauti tyrime neprieštarauja vaiko interesams, sprendžia vaiko atstovai pagal ịstatymą, atsižvelgdami ị tyréjo nuomonę [19].

M. Hallstro ir G. Flander nurodo, kad daugeliu atvejų vienas ar abu tèvai dalyvavo vaiko gydymo ligoninèje laikotarpiu ir dauguma medicininio pobūdžio sprendimų buvo priimami pasitarus su tevais ir vaikais, kuriems taikomas gydymas. Vaiko dalyvavimas, išreiškiant savo nuomonę gydymo procese, padeda vaikui išsiugdyti savo, kaip pagrindinio gydymo proceso subjekto, asmens jausmą ir suteikia tèvams jausmą, kad jie yra komandos, teikiančios vaikui 
gydymą ligoninèje, dalis [17]. Tokia implikacija svarbi vaiko socialinei raidai, ugdymuisi ịsitraukti ị sprendimų prièmimą ne tik sveikatos, bet ir kitais asmens apsaugos klausimais.

Vaiko teisè ị sveikatą ir vaiko sveikatos būklè yra pagrindiniai aspektai, vertinant vaiko interesus. Būtina tinkamai atsižvelgti ị vaiko pažiūras, remiantis jo amžiumi ir branda. Vaikai turetų gauti pakankamą ir tinkamą informaciją, kad galètų suprasti situaciją ir visus svarbius su jų interesais susijusius aspektus, ir, esant galimybei, duoti informuotą sutikimą [18]. Pasaulio sveikatos organizacijos parengtuose Vaikų ir jaunimo priežiūros kokybės gerinimo standartuose nurodoma, kad vaikai ir paaugliai turi gauti ịrodymais ir mokslu pagrịstas sveikatos priežiūros paslaugas, kurios turi būti teikiamos taip, kad atitiktų geriausius vaiko interesus. Vaikas turi būti pagrindinis aspektas ir centrinè ašis, ị ką reikia atsižvelgti, teikiant sveikatos priežiūros paslaugas, kurių organizavimas neatsiejamas su vaiko interesų, vaiko norų ir teisinès tėvų ar globèjų atsakomybès derinimu. Vaikai ir paaugliai turi gauti kiek įmanoma kokybiškesnes sveikatos priežiūros paslaugas. Tai užtikrina vaikų teisę ị sveikatą [20].

\section{Išvados}

1. Vaikai, gaudami pakankamai informacijos sveikatos klausimais, turedami galimybę dalyvauti organizuotoje mokslo įrodymais pagristoje sveikatos stiprinimo veikloje, gali tinkamiau vertinti esamą situaciją, patys inicijuoti veiklas, padedančias suvokti ir nustatyti veiksnius, turinčius itakos sveikatos aplinkai. Tai suteiktų galimybę ir sudarytų prielaidas vystytis vaikų savarankiškumui, didintų jų sveikatos raštingumą, skatintų aktyviai dalyvauti sprendimų prièmime. Suaugusieji turètų prisiimti patarèjo vaidmeni, vaikams dalyvaujant tokioje veikloje.

2. Institucijos, vykdydamos teisès aktuose nustatytas funkcijas bei igyvendindamos strateginiuose dokumentuose numatytus uždavinius ir priemones, turi kompleksiškai taikyti „Sveikata visose politikose“ principą pagal Pasaulio sveikatos organizacijos rekomendacijas. Tai yra užtikrinti tarpžinybinị bendradarbiavimą ir priimant sprendimus vadovautis nuostata, kad vaikų sveikata yra svarbiausias veiksnys užtikrinant geriausius vaiko interesus. Tik taip bus galima sukurti kuo tinkamesnes sąlygas vaikų visapusiam vystymuisi, užtikrinant vaikų teisę ị sveiką ir saugią aplinką, sveikatos apsaugą, vaiko dalyvavimą, sprendžiant su juo susijusius klausimus.

3. Vaiko interesus kiekvienu konkrečiu atveju būtina vertinti atsižvelgus ị esamas konkrečias aplinkybes, laikantis nuostatos, kad vaiko interesai turi būti vertinami, teikiant jiems prioritetą prieš kitų asmenų interesus.

4. Geriausių vaiko interesų principas turi būti taikomas visame JTVTK kontekste, tinkamai išklausant ir atsižvelgiant i̇ vaikų nuomonę bei gerbiant vaikų teisę prisiimti didesnę atsakomybę už sprendimus, atsižvelgiant ị kiekvieno vaiko raidą ir kintančius gebejjimus.

\section{Literatūra}

1. Sormunen MA (Ed.). The best interests of the child - a dialogue between theory and practice. Strasbourg: Council of Europe Publishing 2016:159.

https://rm.coe.int/1680657e56

2. Jungtinių Tautų Vaiko teisių komiteto bendrieji komentarai. Bendrasis komentaras Nr. 14 ,Dèl vaiko teisès pirmiausia atsižvelgti ị jo (jos) interesus“" (3 str. 1 dalis). Jungtinių Tautų Vaiko teisių komitetas, 2013.

https://www2.ohchr.org/English/bodies/crc/docs/GC/CRC_C_ GC_14_ENG.pdf

3. Jungtinių Tautų Vaiko teisių komiteto bendrieji komentarai. Bendrasis komentaras Nr. 12 "Dèl vaiko teisès būti išklausytam". Jungtinių Tautų Vaiko teisių komitetas, 2009. https:// www2.ohchr.org/english/bodies/crc/docs/AdvanceVersions/ CRC-C-GC-12.pdf.

4. Day L, Percy-Smith B, Ruxton S, McKenna K, Redgrave K, Ronicle J, Young T. Evaluation of legislation, policy and practice on child participation in the EU, European Commission, $\mathrm{Pu}-$ blications Office of the European Union, Luxembourg, 2015. https://op.europa.eu/en/publication-detail/-/publication/ 3f3c50b2-6a24-465e-b8d1-74dcac7f8c42.

5. Llorens CJ. Best interests of the child and the right to be heard. Presentation of General Comment No. 14: strengths and limitations, points of consensus and dissent emerging in its drafting. Council of Europe 2016. ISBN 978-92-871-8252-4.

6. Korin MR. (Ed.). Health promotion for children and adolescents. Springer US 2016.

https://doi.org/10.1007/978-1-4899-7711-3

7. Jungtinės Karalystės ir Airijos Respublikos seksualinės ir fizinės prievartos tyrimų ataskaitos: Levy A, Kahan B. The Pindown Experience and the Protection of Children: The Report of the Staffordshire Child Care Enquiry. Staffordshire County Council 1991; The Leicestershire Inquiry 1992; Kirkwood A. Leicestershire County Council 1993; Ronald Waterhouse. Lost In Care, the Tribunal of Inquiry into abuse of children in care in Clywd and Gwynedd. DH/Welsh Office 2000; The Report of the Commission of Inquiry into Child Abuse Republic of Ireland 2009.

8. Brunnberg E, Schuurman M. (Ed.) Speak up! Giving a voice to European children in vulnerable situations. Brussels, Eurochild 2012. https://www.researchgate.net/publication/255785613 Speak_Up_Giving_a_voice_to_European_children_in_vulnerable_situations.

9. Child and youth participation in the Republic of Moldova. A Council of Europe policy review. Directorate General of Social Cohesion. Council of Europe 2013.

https://rm.coe.int/168046c7f9

10. Child and youth participation in the Slovak Republic. A Council of Europe policy review. Justice and Human Dignity Directorate. Council of Europe 2012. https://www.coe.int/t/dg3/children/ 
participation/PolicyReviewSlovak_en.pdf.

11. Davey C, Burke T, Shaw C, Children's participation in decision-making. A summary report on progress made up to 2010. Participation Works, Children's Rights Alliance for England, London 2010.

http://www.crae.org.uk/media/26282/Childrens participation in_decision-making_-_A_childrens_views_report.pdf

12. Children's Rights Alliance for England. Speaking freely - Children and young people in Europe take action on ending violence against children in custody: campaign report, Children's Rights Alliance for England, London 2013. https://resourcecentre. savethechildren.net/node/7122/pdf/7122.pdf

13. Daly A, Ruxton S, Schuurman M. Challenges to children's rights today: what do children think? Council of Europe 2016. https://edoc.coe.int/en/children-s-rights/7205-challenges-tochildren-s-rights-today-what-do-children-think.html

14. Flash Eurobarometer. The rights of the child. European Commission, Brussels 2009. https://dbk.gesis.org/dbksearch/ SDESC2.asp?no $=4987 \&$ search $=$ Flash \&search2 $=\& D B=E$

15. Elsley S, Kay E, Tisdall K, Davidson E. Children and young people's experiences of, and views on, issues relating to the implementation of the United Nations Convention on the Rights of the Child. Scottish Government Social Research 2013. https:/www.research.ed.ac.uk/portal/en/publications/ children-and-young-peoples-experiences-of-and-views-on-issues-relating-to-the-implementation-of-the-united-nations-convention-on-the-rights-of-the-child(ccc0c8c4-ca82-4e52-874afcbaef4a091a).html

16. Hart R. Keynote Participation. A European Conference on linking education with promotion of health in schools. Egmond 2002 .

17. Hallstro MI, Elander G. Decision-making during hospitalization: parents' and children's involvement. Journal of Clinical Nursing 2004;13:367-375.

https://doi.org/10.1046/j.1365-2702.2003.00877.x

18. Jungtinių Tautu vaiko teisių komiteto bendrieji komentarai. Bendrasis komentaras Nr. 15 „Dèl vaiko teisès naudotis tobuliausiomis sveikatos sistemos paslaugomis“" 24 str.). Jungtiniu Tautų Vaiko teisių komitetas, 2013. http://vtaki.lt/uploads/ structure/docs/485 a5eebb22a7f392edf2d7634481bb46b5.pdf

19. Lietuvos Respublikos biomedicinių tyrimų etikos įstatymas. https:/e-seimas.lrs.lt/portal/legalAct/lt/TAD/7aa28cc261bb1 $1 \mathrm{e} 5 \mathrm{~b} 316 \mathrm{~b} 7 \mathrm{e} 07 \mathrm{~d} 98304 \mathrm{~b}$

20. World Health Organization. Standards for improving the quality of care for children and young adolescents in health facilities. WHO, 2018. ISBN 978-92-4-156555-4. https://apps.who. int/iris/bitstream/handle/10665/272346/9789241565554-eng. pdf?ua $=1$

\section{CHILDREN PARTICIPATION: HEALTH CARE AND RIGHT TO TAKE DECISION A. Astrauskienė, A. Šidlauskienė, R. Pabedinskienė, D. Bernackienè, J. Alsytè-Gogelienè}

Keywords: child rights, child participation, best interests of the child.

\section{Summary}

The aim of this article is to analyse the tendencies of Childparticipation in the field of health care, to present the changes in the context of the United Nations Convention on the Rights of the Child, the Council of Europe Strategy on the Child Rights as of 2016-2021, health care and education legislation in Lithuania. The principle of best interests of the child, which may be misunderstood in application, is reviewed. Various misunderstandings in application of the principle of the best interests of the child may harm the implementation of the child's rights or endanger the child.

An overview of documents, commentaries on documents and articles on the protection of the Rights of the Child in the historical perspective has been made. It should be noted that in the field of health care, the participation of the child is one of the essential elements in ensuring the best interests of the child. Ensuring the principle of the child's participation, when listening out to the child's view, in the health care system enables the child to influence his or her treatment process and at the same time to include the child in the health care system as an equal entity represented by the child's parents or other representatives by law. It is important to note that the participation of the child creates conditions and preconditions for ensuring the implementation of the child, as a holder of his or her own rights in the family and public life by realizing his or her rights in the health, education, social and legal systems.

Conclusions. Children, by receiving sufficient information on health issues and having the opportunity to participate in organized evidence-based health promotion activities, can better assess the current situation and initiate activities themselves to understand and identify factors influencing the health environment. This would provide an opportunity and create preconditions for the development of children's independence, increase their health literacy, encourage active participation in decision-making. Adults should take on the role of counselor, with children participating in such activities. In implementing the functions set out in the legislation and the tasks set out in the strategy papers, the institutions shall be guided by the World Health Organisation's principle of „Health in All Policies", ensure intersectoral cooperation and take children's health into account in decision-making. Only in this way it will be possible to create the most appropriate conditions for the full development of children, ensuring children's right to a healthy and safe environment, health protection, and the child's participation in solving relevant issues. The best interests of the child shall be a matter for each case, taking into account the particular circumstances of the case, in accordance with the principle that the best interests of the child shall be a primary consideration for others. The principle of the best interests of the child shall be applied throughout the content of the UN Convention on the Rights of the Child and with due regard for and consideration of the views of children and respect for children's right to take greater responsibility for decision-making in the light of each child's development and changing abilities.

Correspondence to: ruta.pabedinskiene@gmail.com

$$
\text { Gauta 2021-03-05 }
$$

